\title{
THE IMPACTS OF FOOD TABOOS \\ AND PREFERENCES ON FOOD SECURITY \\ IN DEVELOPING COUNTRIES: \\ EVIDENCE FROM ETHIOPIA
}

\section{DOPADY POTRAVINOVÝCH TABU A PREFERENCIÍ NA POTRAVINOVÚ BEZPEČNOSŤ V ROZVOJOVÝCH KRAJINÁCH: DÔKAZY Z ETIÓPIE}

\author{
Alex SEWENET* - Pavol SCHWARCZ*
}

\section{Introduction}

Food norms are written and unwritten standards that govern people's economic behavior. ${ }^{(1)}$ They instruct individuals of a society about the dos and don'ts concerning production, distribution, and consumption of food. Written food norms are part of laws and enforced by the state through the law enforce-

\section{Abstract (EN)}

Food norms are embodied within all the essential components of food security; availability, access, utilization, and stability. However, the adverse economic influences of these norms are largely under-researched in developing countries. Unique in its scoop, this study thus investigates the impacts of food taboos and preferences (FTP) on food security in Ethiopia, one of the world's food-insecure nations combined with a culture of strict food norms. On the basis of a qualitative research design with semi-structured in-depth interviews, primary data was collected from eleven key informants of pertinent multidisciplinary backgrounds, experts and decision-makers. The empirical evidence revealed that religious and secularbased FTP have put significant restrictions on the efficient utilization of the existing edible resources in the country. For example, during Orthodox Christian (OC) and Muslim fasting days, the overall food supply chain undergoes economic turbulence. Particularly, the economic challenge of $\mathrm{OC}$ fasting is expressed by (1) a decrease in consumption and supply of non-vegan foods, (2) the temporary closure of butcher and dairy shops, (3) an increase in the demand and price of vegan foods, and (4) an overall reduction in consumption and economic transactions. Moreover, the tradition of animal consecration at home has made many Ethiopians to rarely depend on supermarkets, groceries, and other licensed meat shops. In turn, this impedes the country's endeavor of attracting local and foreign private investors in the general food sector. It also alienates people from access to food labels, meat quality controls, price, size, and choice advantages, all of which are essential for better, adaptive, and stable food utilization. The results discovered in this thesis enrich our understanding on the role of food norms in the economic systems. Particularly, the study sheds light on the indispensable need to consider the subject of FTP in policies and programs aiming to end food insecurity.

\section{Keywords (EN)}

Food Security; Food Taboos; Food Preference; Culture; Ethiopia

Slovak University of Agriculture in Nitra, Slovakia ment agencies ${ }^{(2)}$, whereas unwritten food norms are handled through informal social control mechanisms. ${ }^{(3)}$ An example of informal social control is the use of positive and negative sanctions by kin or wider society as admiration and social exclusion for conformists and deviants, respectively. ${ }^{(2)}$ Within this context, food taboos and preferences (FTP) are specific

\section{Abstrakt (SK)}

Potravinové normy sú súčastou všetkých základných zložiek potravinovej bezpečnosti a to: dostupnosti, prístupu, využitia a stability. Negatívne ekonomické vplyvy týchto noriem sú však v rozvojových krajinách doposial' nedostatočne preskúmané. Predkladaná štúdia sa preto zaoberá dopadmi potravinového tabu a preferencií na potravinovú bezpečnost' $v$ Etiópii, ktorá patrí ku krajinám nedostatočne zabezpečenými potravinami v kombinácii s kultúrou prísnych potravinových noriem. Na základe kvalitatívneho výskumu, použitím pološtruktúrovaných rozhovorov, boli zhromaždené primárne údaje od jedenástich klúčových informátorov z relevantných multidisciplinárnych prostredí, odborníkov a osôb s rozhodovacími právomocami. Empirické dôkazy odhalili, že náboženské a sekulárne potravinové tabu a preferencie zaviedli výrazné obmedzenia na efektívne využitie existujúcich zdrojov jedla v krajine. Napríklad počas dní pôstu ortodoxných krestanov a moslimov prechádza celkový potravinový retazec hospodárskymi turbulenciami. Ekonomické výzvy počas pôstu ortodoxných krestanov sú spôsobené najmä (1) poklesom spotreby a ponuky nevegánskych potravín, (2) dočasným zatvorením mäsiarstiev a mliekarní, (3) zvýšením dopytu a cien vegánskych výrobkov a (4) celkovým znižením spotreby a ekonomických transakcií. Tradícia posvätenia domácich zvierat navyše spôsobila, že množstvo etiópčanov nie je závislých od supermarketov, potravín a iných licencovaných obchodov s mäsom. To zasa bráni prilákaniu miestnych a zahraničných súkromných investorov do potravinárskeho sektoru. Takéto praktiky tiež pôsobia ako prekážka pre ludí pri oboznamovaní sa s označením potravín, kontrolou kvality mäsa, cenou, velkostou a výhodami výberu, čo sú všetko nevyhnutné predpoklady pre lepšie, adaptívnejšie a stabilnejšie využitie potravín. Výsledky štúdie prispievajú k pochopeniu úlohy potravinových noriem $v$ ekonomických systémoch. Štúdia ozrejmuje predovšetkým nevyhnutnú potrebu zvážit tému potravinových tabu a preferenciú v politikách a programoch zameraných na odstránenie potravinovej neistoty.

\section{Klúčové slová (SK)}

potravinová bezpečnost', potravinové tabu, potravinové preferencie, náboženstvo, kultúra, Etiópia 
components of food norms ${ }^{(1)}$ Consecutively, they refer to the prohibition of a particular food or drink from consumption and the selection of what is most important from the socially recognized food. ${ }^{(4)(5)}$

FTP are neither absolute nor static ${ }^{(1)}$ They constantly change depending on society's demand, research findings, change in people's awareness, and adaptation. ${ }^{(7)}$ In many Western societies, for instance, people used to consider entomophagy as unpleasant or taboo. ${ }^{(8)}$ However, today this attitude is gradually changing following the growing and consistent research findings of the health, environment, and sustainability benefits of insect diets. ${ }^{(8)}$ Furthermore, FTP are the outcomes of religious and secular factors. ${ }^{(9)}$ Therefore, they differ across societies and so does their impacts on countries' food security vary. ${ }^{(1)(9)}$

Food security is comprehended based on four major components, namely food availability, access, utilization, and stability ${ }^{(10)}$. All these constituents are overwhelmingly impacted by food taboos and preferences. These impacts, on the one hand, can be both positive and negative, though this thesis focused on the latter. On the other hand, they tend to be more powerful and overt in societies with strong social norms. In this regard, Ethiopia serves as an illustrative case within this study, being one of the world's most food-insecure nations with persistent food norms. The strict nonscientific FTP that are deeply rooted in the country's religious, cultural, and traditional beliefs are believed to have adverse impacts on its food security thereby further worsening the prevailing food insecurity of the country. ${ }^{(11)(12)}$

For over three decades, Ethiopia has been extensively quoted across the world as an instance of chronic food insecurity. ${ }^{(13)}$ This seems to be due to the 1984 - 85 ravage famine, which killed and internally displaced 1.2 and 2.5 million people respectively. ${ }^{(14)}$ However, since the end of the 1990s, the country has managed to become one of the fastest economically growing nations in the world with an average 8 percent GDP boost. ${ }^{(13)}$ The effort has paid off in the country and reduced its Global Hunger Index (GHI) by a total of 26.8 within 18 years, 2000 2018. ${ }^{(15)}$ But the progress is not left without criticism. It is stated that the success gained at the macroeconomic level is not properly trickling-down to reach the destitute and help them break the vicious circle of poverty. ${ }^{(13)}$ Hence, the country has remained among the top 20 globally food-insecure nations. ${ }^{(15)}$ Thus, the Ethiopian government has endorsed a set of national strategic policies to become among the lower-middle-income

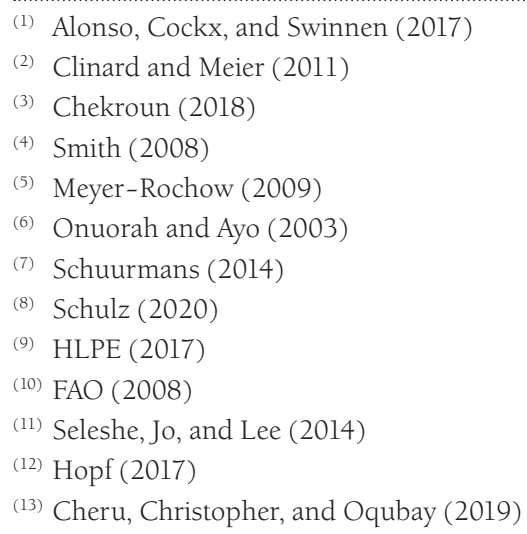

countries by $2025^{(16)}$ and to achieve the "no poverty" and "zero hunger" goals of the Agenda 2030(17), which involves sustainable food security ${ }^{(16)}$.

Fundamental to national food security yet often overlooked by concerned authorities are food norms. ${ }^{(1)}$ As FAO exposed, nonscientific based normative food restrictions are among the reasons for the poor utilization of the existing nutritional plant and animal species in some African countries ${ }^{(1)}$ In fact, countries with rich biodiversity have a potential comparative advantage of food availability and access over others with more limited resources ${ }^{(18)}$ However, the presence of rich animal and plant species does not necessarily mean more food. The case of Ethiopia is a good illustration. Ethiopia is among the top-ranked most biodiverse African countries. ${ }^{(19),}{ }^{(20)}$ The comprehensive weather conditions, which range from tropical to cool zones and elevation as high as Mt Ras Dejen, 4533 meters above sea level, and as deep as the Denakil Depression, 116 meters below sea level ${ }^{(1)}$, have made the country a home for 6000 plant, 861 bird, 200 fish, 201 reptile, 1225 arthropod, 63 amphibian, and 284 wild mammal species. ${ }^{(19)}$ Some wild animals and insects are not properly registered yet. However, the number of animals and plants species recognized in the mainstream food culture are extremely limited for reasons related to religion, lack of awareness, and belief-based FTP. ${ }^{(11)(12)}$

In the fight against food insecurity in Ethiopia, the core political and economic bottlenecks and the way forward have been debated for decades in academic and non-academic discourses. ${ }^{(13)}$ Therefore, this paper deviates from this widely argued conventional outlooks and instead focused on investigating one of the least uncovered but equally important drivers of food security, namely food norms. ${ }^{(1),(9),(21)}$ Specifically, this thesis addresses the impacts of culturally and religiously based FTP on Ethiopian food security.

\section{Problem Statement}

Scientific based FTP are positively recommended from health and sustainability perspectives ${ }^{(4),(5)}$. However, those FTP that depend on non-scientific roots, which are widespread in Ethiopia, are thought to have some adverse implications on food security. ${ }^{(11),(12),(13)}$. Just to mention a few, taken-for-granted food taboos and preferences can cause unconsulted food bans, poor dietary choices, and inconsistencies on production and consumption patterns which are all related to the main components of food security.(1) For example in Ethiopia, fasting is a dominant religious ritual that significantly affects the overall food demand and supply chains, food choices, and the frequency of daily calorie intakes. ${ }^{(23)}$ After all, fasting constitutes a major reason that Ethiopians belong to one of the most vegetarian people in the world. ${ }^{(22)}$ This is because it imposes strict
(14) Gill (2010)
(15) WFP and CSA (2019)
(16) WB (2019)
(17) UN (2015)
(18) FAO (2019a)
(19) EBI (2014)
(20) Crummey and Mehretu (2019) 
rules on what and when to eat. However, the particulars vary depending on the specific guides of each religion, in this case OC and Islam.

For Ethiopian OC, fasting goes accompanied with abstinence from consumption and selective food proscription. ${ }^{(23),(24)}$ The practice has been in force since the $4^{\text {th }}$ century when Christianity was introduced in Ethiopia. ${ }^{(24),(25)}$ The Ethiopian Orthodox Tewahedo Church (EOTC) defines fasting as a sacred sacrament whereby the believers get spiritually connected and seek salvation through reducing physical comfort as per Saint Paul's Biblical guidance to "chastise the body and bring it under subjection" (1 Cor. 9:27 King James Version). During these days, believers abstain from taking any food and drink before 3.00 $\mathrm{pm}$, after which their diet includes only vegan food.(23), (24) In other words, during the fasting days, the consumption of any type of meat, including fish and animal products like egg and dairy, is strictly prohibited. The fasting counts at least half of the days in a year, although the exact number of days depends on who practice them, laymen or clergy. Unlike OC, fasting in Islam is not food-specific. (26) Instead, it is manifested by a willful renounce of any types of foods, drinks, smokes, and sexual activities from sunrise to sunset during each fasting day.

(26) Ramadan, a tribute to Nebyu Muhammad's first revelation, is the most popular one-month fasting and practiced by all healthy and non-traveling adult Muslims worldwide.

Numerical evidence on how many OCs and Muslims adhere to fasting in Ethiopia is incomplete. Nonetheless, the centuries-old footprints of the two religions on the overall social structure of the country in combination with the large number of followers have made the effect of fasting to appear explicitly on the production and consumption of some food items. ${ }^{(11),}$ (12), (25) A recent national quantitative study by D'Haene et al. revealed that OC fasting has an adverse impact on milk consumption and production patterns. Not only OCs but also the followers of other religions are impacted, due to a spillover effect described in the study. Another similar study ${ }^{(24)}$ also came up with the same results on biscuit production and consumption.

Additionally, there is evolving evidence in academic literature that demonstrates how granted FTP in different societies can affect food security by constraining people to get essential micronutrients. For instance, in some rural areas of Ethiopia, pregnant women have no free dietary choice due to belief-based food taboos. ${ }^{(27)}$ Particularly, in the central Ethiopia rural Arsi district, pregnant women limit the consumption of green leafy vegetables and dairy products. ${ }^{(27)}$ In their belief, this food taboo reduces possible childbirth complications and pains through losing weight during pregnancy. However, the practice is neither encouraged nor enacted by the law. Similar studies on the impacts of food taboos among pregnant women

(21) Olum, Okello-uma, Tumuhimbise, Taylor, and Ongeng (2017)

(22) Rogers (2020)

(23) D'Haene, Desiere, D'Haese, Verbeke, and Schoors (2019)

(24) Belwal and Tafesse (2010)

(25) Esler (2019)

(26) Sadeghirad, Motaghipisheh, Kolahdooz, Zahedi, and Haghdoost (2012)

(27) Zerfu, Umeta, and Baye (2016) are also conducted in Nigeria( ${ }^{(28)}$, Ghana ${ }^{(29)}$, Malawi ${ }^{(30)}$, and Ne$\mathrm{pal}^{(31)}$. Some of these research findings showed that the existing belief-based food taboos might be detrimental to the health of both the pregnant women and fetuses. This is because the taboos can prevent them from getting the proper proteins and other micronutrients.

The points covered in this section are just a few examples to emphasize the importance of the topic under discussion. However, the details on the adverse impacts of nonscientifically based FTP on food security are commonly given less attention in academic and non-academic studies in developing countries. In Ethiopia, the few existing studies related to the subject are neither exhaustive nor taking food security sufficiently into account. They mainly focused on the impacts of OC fasting on the production and consumption of certain food items such as milk ${ }^{(23)}$, biscuit $^{(24)}$, and meat ${ }^{(11)}$. Furthermore, policy cycles aiming to enhance food security are more biased towards the technology, market, and political subjects than the food norms ${ }^{(1)}$. Therefore, this study addressed the aforementioned literature gap by investigating the adverse impact of nonscientifically based FTP on food security through collecting evidence from Ethiopia.

\section{Conceptual Definitions}

\subsection{Food Security}

The meaning of food security unfolds more prominently in the international dialogue during the 1970s, although there were already some concerns and discussions about the subject in the 1940s. ${ }^{(33)}$ Initially, only few variables such as production and supply were used to operationalize the concept. However, through time the meaning of food security started to expand and became multi-dimensional. The breakthrough for the contemporary comprehensive definition of food security, the one adopted in this thesis, goes back to the World Food Summit of 1996. In the meeting, it is put forward that "food security exists when all people, at all times, have physical and economic access to sufficient, safe and nutritious food that meets their dietary needs and food preferences for an active and healthy life"(33) (World Food Summit, 1996). Based on this definition, food security comprises four essential components; food availability, access, utilization, and stability of food. ${ }^{(10)}$ Besides, humans' ways of life or cultures, which are expressed in the form of food norms impacts each of the four components of food security.(1)

Food availability refers to whether people have sufficient and nutritious food to eat, gained either through their own production or external sources. ${ }^{(34)}$ It is particularly concerned with the production, distribution, and exchange of food items. Like-

\footnotetext{
(28) Abidoye and Akinpelumi (2010)

(29) Aikins (2014)

(30) Maliwichi-Nyirenda and Maliwichi (2017)

(31) Christian et al. (2007)

(32) Maxwell1(996)

(33) World Food Summitl(996)

(34) WFP (2009)
} 
wise, individuals' and households' ability to acquire a healthy and nutritious diet is related to food access. Food availability does not necessarily guarantee accessibility nor does accessibility ensure utilization ${ }^{(34)}$ After all, affordability, allocation, and cultural factors also affect accessibility and utilization.

Food security is maintained when the source of the food is stable. As shown in Figure 3.1, food stability affects all other components of food security. Hence, the attainment of one or two of the food security components does not ensure an individual or a group to declare food security. Instead, all the four components have to be successfully maintained. ${ }^{(10),(33),(34)}$

Figure 1: A framework illustrating the relationship between the four components of food security ${ }^{(35)}$

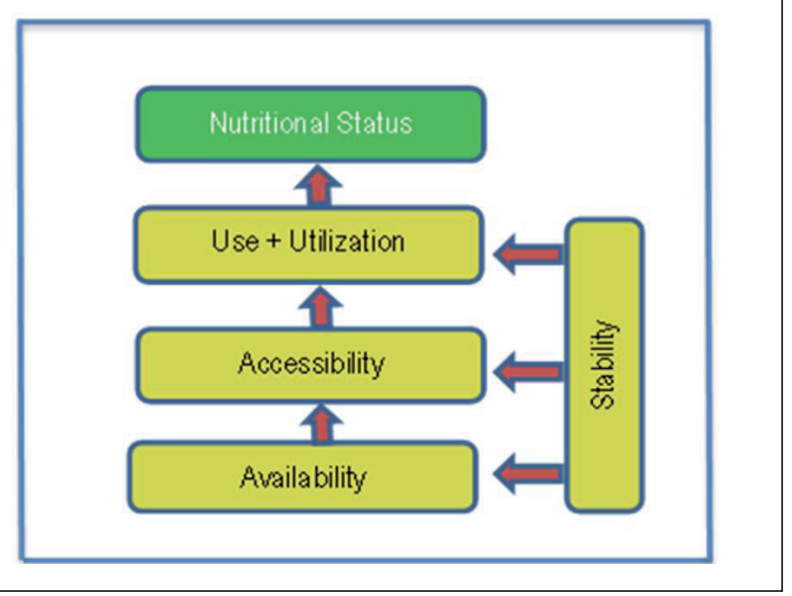

\subsection{Food Taboos and Preferences}

The conceptual definitions of FTP adopted in this article are not different from their conventional meanings. Food taboos are socially or religiously based norms or laws that prohibit people to consume certain types of food. ${ }^{(5)}$ For the purpose of this study, temporary food prohibition that results from fasting and other normative restrictions are also considered and included in the definition. Conversely, food preference is the choice of a particular food or drink over others based on norms or laws. ${ }^{(4)}$ Otherwise stated, it is the selection of what is most important from the available and socially recognized foods.

\section{Study Area and Research Design}

\subsection{Background of the Study Area}

Ethiopia, the study site around which this study revolves, is also known as "land of origins." The country is a landlocked and located in the Horn of Africa, bordering Kenya in the South, Eretria in the North, Somali in the East, Djibouti in Northeast, South Sudan in the West and Sudan in Northeast. It has a total land size of 1.1 million square kilometer and diverse geographic and climatic conditions. ${ }^{(15)}$ As of 2020, the country has a total of 114.5 million people with a 2.57 percent population growth rate, making it the second most populous nation of the African continent after Nigeria. ${ }^{(36)}$ Ethiopia has around eighty different ethnic groups although over 60 percent is only from the two largest ethnic groups, namely Oromo and Amhara. ${ }^{(37)}$ Almost all ethnic groups have their own legally recognized language that they use as a mother tongue, while Amharic is the federal government's working language.

Religion has a strong public support base in Ethiopia. ${ }^{(25)}$ Article 11 of the Ethiopian Constitution stipulates the separation of state and religion. Hence, the country is officially a secular state. Citizens are thus granted the constitutional right to religious choice, though informal pressure among family members and closer kin to perpetuate the religion of their parents is common among all religious categories. According to the Central Statistics Agency of Ethiopia, ${ }^{(38)} 97$ percent of the Ethiopians associate themselves with one of the main religious categories, namely OC (43.5 percent), Islam (34 percent), and Protestant (18.5 percent) and Catholic Christians ( 1 percent). Introduced in the $4^{\text {th }}$ and $7^{\text {th }}$ centuries respectively, $\mathrm{OC}$ and Islam have played paramount roles in the state formation. ${ }^{(37)}$ Especially, the EOTC has a strong influence on the overall socio-economic and political culture of the county. It is hardly possible to comprehend the Ethiopian overall history, culture, and social institutions independent of the EOTC.(25) The Church used to function complementarily with the state for centuries until the first secular government was established in 1974. (25), (37)

Ethiopia is a historically rich and culturally diverse country. Sub-cultures are very common among the different ethnic groups. (12), (37) Group life is highly valued, which goes at the expense of individualism. In fact, strong solidarity is essential to people's livelihood strategy in the country. in relation with this social cohesion, norms are very powerful, particularly in the countryside. ${ }^{(12)}$ Religion is plays a catalyst role in ensuring that people are still connected to each other and adhered to the shared core spiritual values. So, in practice, there are no clear cut boundaries between religious and non-religious lifestyles. ${ }^{(25)}$ After all, many of the country's secular cultural components originate from EOTC influence. There are many religious and secular rituals and holidays the people attend and express their religious and/or secular value, honor, and sentiment (Esler, 2019; Hopf, 2017). The country's ability to maintain its sovereignty during colonial times has granted an opportunity to safeguard many of its indigenous knowledge. ${ }^{(12),(37)}$

Agriculture is the engine of Ethiopia's economy and it has a substantial spillover effect on other sectors. ${ }^{(13)}$ In 2015-16, agriculture in Ethiopia contributed 36.7 percent of the national GDP, 72.7 percent of the total employment, and 90 percent of the total export. ${ }^{(14)}$ Moreover, the sector is characterized by low productivity, the dominance of family-based subsistence farmers, labor-intensive farming, high dependency on rain, and exposure to the adverse impacts of the reoccurring drought of the region. ${ }^{(13)}(15)$

Since the beginning of the 1990s, the Ethiopian government has shown immense interest in the Asian based developmental

\footnotetext{
(35) Napoli (2011/12)

(36) Worldometer (2020)

(37) Adamu (2013)
} 
state philosophy. ${ }^{(39)}$ In line with this philosophy, the Ethiopian government is in control of major economic assets, including land, and plays a pivotal role in the main economic activities. ${ }^{(13)}$ However, private sectors are not completely banned, as was the case under the socialist Derge Regime (1974 - 1987). Instead, the government encourages private sectors to engage in different economic activities, albeit few giant national projects like telecom and national aviation industries remain under the sole control of the state. ${ }^{(13),(39)}$

Agricultural Development Led Industrialization (ADLI) is the national economic policy targeting the countryside. It is based on the logic that a higher efficiency and effectiveness of agriculture are the safe ways for the country's transition to industrialization. Indeed, from developed countries' experience, technology and capital supported agricultural productivity facilitates rural transformation. ${ }^{(40)}$ In the long run, this process involves a decrease of agriculture as a factor of income and agriculture's contribution to the national GDP, compared to industry and service sector economic activities. ${ }^{(41)}$ This process also holds a gradual decline in the number of people engaged in the agricultural sector. ${ }^{(42)}$ The idea has also been discussed in the Arthur Lewis structural model, where the process is noted as an ideal opportunity to get idle labor which can in turn be used to fill the labor gap in other sectors. ${ }^{(43)}$ However, its pertinence in developing countries has been doubted, due to a number of contextual factors. ${ }^{(43)}$

\subsection{Research Methods and Samples}

The main research question of the study demands an understanding and description of thoughts, experiences, and concepts. In other words, the topic of the thesis is tangled to the society's socio-cultural and religious variables. Accordingly, it requires rich data to properly address the thesis' ultimate objective. In a study of the aforesaid features, qualitative research is more appropriate than quantitative study. ${ }^{(44),(45)}$.

Therefore, this exploratory study employed a cross-sectional qualitative research design, with semi-structured in-depth interviews as the main method of data collection. Cross-sectional design means that the data are collected at a single point in time. ${ }^{(46)}$ Hence, this research did not examine the over-time changes of the subject, as is the case in longitudinal studies. Specifically, in-depth interviews were used because of the relative flexibility of the method. ${ }^{(47)}$ In-depth interviewing enabled both the researcher and interviewees to thoroughly discuss the themes in one-to-one interviews. ${ }^{(48)}$ In addition, the study was supplemented with pertinent research findings and reports cited from academic books, journal articles, web-pages, and gov-

\footnotetext{
(38) CSA (2010)

(39) Clapham (2018)

(40) Bhandari and Ghimire (2016)

(41) Arendonk (2015)

(42) Dennis and Talan (2007)

(43) Todaro and Smith (2015)

(44) Taylor, Bogdan, and DeVault (2016)

(45) Flick (2018)

(46) Payne and Payne (2004)

(47) Wertz, Charmaz, McMullen, Anderson, and McSpadden (2011)
}

ernmental and non-governmental reports. Reliable information and research findings obtained from these sources were combined with the primary data to substantiate and enhance the analysis and discussions.

Primary data were collected from 11 key informants who are different stakeholders, experts, and decision-makers that can properly judge the ongoing issues. The selection of the samples was done by the researcher in between December 13, 2019 to January 25, 2020. To identify the right units of analysis, all the key informants were purposively selected based on professional experience, educational background, and international exposure criteria. Because Ethiopian food norms are related to religion, culture, history, and traditional belief,,(12), (24), (25) the samples were chosen from various multidisciplinary backgrounds. All the key informants were from Ethiopian origin and the majority used to live in the national capital, Addis Ababa. The sample size was determined based on the level of data saturation, though a balance is made to include key informants from all the aforesaid selection criteria. The interview with the key informants took place virtually from mid-February to the end of May 2020.

\section{Findings}

\subsection{The Mainstream Food Taboos and Preferences}

From the evidence collected, it is noted that within the mainstream Ethiopian food norms, food prohibitions or taboos are expressed in different forms. The first and most common are unconditional food taboos. These taboos represent those foods, which are completely banned from the country's mainstream food menu through existing norms for religious or secular reasons. Examples include pork, donkey and horse meat, and seafood except fish.

The second types are conditional food taboos. According to the key informants some foods can remain in the taboo lists unless they fit into the religiously and/or culturally defined normative standards. One notable example is the need to pray before slaughtering edible animals. "Religiously permitted animals have to be consecrated based on the religion's tradition to be part of the diet. Otherwise, they remain in the taboo food lists", said the OC and Muslim religious leader key informants. Consequently, Ethiopian OCs and Muslims do not share meatrelated dishes. Alternatively, the vast majority of Ethiopians prefers to buy living animals and bless them in their homes. In a further clarification the sociologist key informant said:

\section{Buying chicken, sheep, and goat meat in supermarkets or other groceries is considered an act of dishonoring the tradition, espe- cially in the countryside. Eatable animals have to be blessed at home. It is one of the most valued rituals of meat consumption among Ethiopians.}

Fasting based abstinence is the third type. During Ethiopian OC and Muslim fasting days, what to eat and when to eat are

\footnotetext{
(48) Rubin and Rubin (2004)

(49) Abaïdia, Daab, and Bouzid (2020)
} 
precisely defined by the dogmas of each of the religion as described in section 2. For instance, OCs fast at least half of the days in a year, fragmented in different days and seasons. This includes almost every Wednesday and Friday, and the 55 consecutive days of Lent fasting before Easter. During all these and other fasting days, OC believers abstain from taking any food or drink before $3.00 \mathrm{pm}$, after which their diet includes only vegan food. ${ }^{(23),(24)}$ Similarly, during Ramadan, (Ethiopian) adult and healthy Muslims abstain from foods, drinks, smokes, and sexual activities from sunrise to sunset for one month. ${ }^{(49)}$ Ramadan is the most popular one-month fasting and practiced by all healthy and non-traveling adult Muslims worldwide, including Ethiopian. According to the $\mathrm{OC}$ and Muslim religious leader key informants, deviation from these spiritually defined fasting in both religions is equally as condemned as eating taboo foods.

Concerning food preference, it is found that religion, culture, and commonly held public perceptions mark the boundary between taboo and non-taboo foods. Scientific or health-based perspectives have limited influence on people's food preferences. Foreign and taboo foods are hardly seen on any of the mainstream food menus. The exceptions are a few high-class hotels and restaurants, which have international customers and thus offer foreign foods and cuisines that are not indigenous and often unfamiliar to the majority of Ethiopians. The interviewee from rural development discipline underlined:

Many people are scared to move beyond the psychologically and culturally drawn mainstream food wall. Food venture and scientific analysis of the nutritional content of the food are not common among the general public. The exceptions are some Ethiopian Diasporas, few educated people, and sick people with medically defined food prescriptions.

From the socially recognized food lists, people's daily choices are made based on palatability, accessibility, and income levels. As the sociologist key informant describes it:

If not constrained by economic limitations, the consumption of meat with alcoholic drinks is the dream food choice for most Ethiopians. Consumption of meat is an expression of high economic and social class which is an extension of centuries-old Ethiopian royal families' food choices. Conversely, the poor are pushed to different types of staple vegan foods such as grains, cereals, puls$e s$, and some vegetables and fruits.

According to the diaspora key informant, "the rich-poor food categorization in Ethiopia is in favor of the poor. The poor eat healthy organic vegan food, which are scientifically recommended, whereas the rich mostly consume meat, dairy products, and too many alcoholic drinks." The relatively low price of vegan food compared to non-vegan foods in the country has made the rich-poor food classification to appear as described above. "The cause for the high price of meat and dairy products in the country is the acute shortage of supply," said the economist key informant.

As noticed from the interviewees' response, seasons, stereotypes, lack of awareness, and misconceptions are also among the factors which influence food preferences. It is also noted that summer and spring are relatively the most challenging seasons for many subsistent farmers in Ethiopia. They face chronic food shortages and have very limited food choices. Conversely, in autumn and winter after the farmers start to collect the fruits of their harvest, they have relatively diversified diet.

Furthermore, since a long time, stereotypes and beliefs have been preventing Ethiopians from the consumption of certain types of edible plant and animal species, as revealed by five research participants. According to the sociologist key informant:

People in the South are heavily dependent on different types of tubers, leaves, and other plant species. This is the result of the rich biodiversity of the region and the easy accessibility of the plants. But, eating some of these vegan foods has been negatively stereotyped, though the labeling is decreasing gradually.

In addition to this point, the nutrition key informant said: "still today some people in the North associate goat meat with bad spirits which can cause sickness."

\subsection{The Impacts of Food Taboos and Preferences on Food Security}

The interviewees were asked to describe and explain the adverse impacts of the prevailing FTP on the country's food security. We begin the analysis from the response of the economist key informant who stated the following about fasting: "the core concept of fasting is abstinence from food and drinks. In a basic economic view, if there is no consumption, there will not be production. Hence, the entire food supply chain from production to consumption will be adversely impacted."

OC fasting is food-specific. It bans meats and other foods of animal origin. Thus, during fasting days, the consumption of prohibited foods and drinks significantly drops in many parts of the country. The subject is consistently discussed in detail by some scholarly studies. According to the key informants, to maintain the profit, some companies limit the production of less demanded foods and drinks. Others divert their businesses to vegan food. Elaborating on the situation, the key informants in Addis Ababa University stated:

During OC fasting days, many local and village butchery and dairy shops and some restaurants temporarily close until the fasting is over. Some others divert to the provision of vegan products. Non-fasting people including the followers of other religions would have very limited access for the band foods due to shortage of supply. OC owned shops who fail to adhere to the church's command can lose customers in non-fasting days as part of the public informal social control sanctions.

Some key informants do not confine the adverse economic implication of fasting to the reduction of consumption. "The booms and busts on the consumption of certain products can have a discouraging effect on the country's attempt of attracting local and foreign investors in the sector," said the economist key informant. He also added that the economic consequences of OC fasting can be worse on easily perishable products like meat, milk, butter, yogurt, and others. According to FAO, with over " 57 million cattle, 30 million sheep and 23 million goats, and 57 million chicken, as well as camels, equines and a small number of pigs", Ethiopia is among the top-ranked African countries in livestock population. ${ }^{(50)}$ However, the meat and dairy supply-chains are very poor and not 
developing. ${ }^{(51),(52)}$ The sector is not a preferred business by local and foreign investors. "Throughout Ethiopia, including the urban regions like Addis Ababa, dairy is mainly distributed and consumed in a traditional way." ${ }^{(52)}$ Among other reasons, this is due to the market constraints that are often caused by fasting-induced inconsistencies in demand and supply. ${ }^{(23)}$ The few existing dairy and meat prosing plants in the country are largely concentrated in the national capital, Addis Ababa. ${ }^{(51)}$

Likewise, the impact of OC fasting on the price and supply of substitutive vegan foods has also been conferred by the research participants. According to the economist key informant, "the price of vegan foods increases as a result of high demand during OC fasting days. The demand increases because vegan foods are the major substitutive of non-vegan fasting foods. Hence, a shortage of supply in vegan foods is created, and this is a common experience in many parts of the country." From the sociologist key informant viewpoint, OC fasting has also a spillover effect on the consumption of some vegan foods, particularly on alcoholic drinks. As he puts it, "many people in Ethiopia drink alcohol after they eat protein-rich foods, commonly meat. Thus, the consumption of alcohol goes down during OC fasting." The fasting wave of influence can go broader. As the diaspora key informants stated, "economic sectors are interdependent. When one sector is affected, there is a high possibility to see ripple effects on other sectors."

Muslims' fasting has also economic outcomes. According to the interviewees, it encounters a decline in business transactions but in a different form than stated for OC fasting. The details are explained by a key informant in AAU of the department of philosophy:

Muslims' fasting is followed by abstinence from all form of foods and drinks for half of the hours of each fasting day, from sunrise to sunset. This reduces consumption. Although shops remain open there is some unevenness in opening and closing hours among Muslim owned businesses.

Fasting is one of the religious rituals, supposed to be practiced on the individual believer's free will. However, the result of this study reveals the existence of strong informal societal pressures on non-fasting OCs and Muslims. It is reported by all research participants that many of the informal pressure comes from family, peers, neighbors, and church leaders. "This is one of the manifestations of the strong value of religion and social bond among people in the country," said the sociologist key informant.

Abstinence from food and drinks for some hours is part of religious commitment during fasting days. The interviewees have provided contrasting views on its socio-economic and health implications. While the OC religious leader key informant said, fasting gives people spiritual and psychological satisfaction and inspires them for work; a nutritionist expert came up with a different view. According to her:

To my knowledge, elderly people, some children, pregnant women, and people with preexisting medical cases also involve in fasting. These are people who need special dietary care. I also know

\footnotetext{
(50) $\mathrm{FAO}$ (2019b)

(51) Abebe, Zelalem, Mitiku, and Yousuf (2020)

(52) Soethoudt, Riet, Sertse, and Groot (2013)
}

some people who ignore their medical prescriptions during fasting days, exposing themselves to poor health conditions.

A few research participants have also revealed the possible impacts of fasting on the farm productivity. According to the economist key informant:

In Ethiopia, almost all the people in the countryside make their livelihood from agriculture or related occupations. Technologies are limited, farming is labor-intensive. Women, children, men, all have roles. They work for hours or a full day with an empty stomach during fasting days. Many do not even drink water for many hours during fasting days as a religious commitment. I understand what it means spiritually but from the scientific perspective, the productivity of labor depends on healthy and mental fitness, which involves a healthy and timely diet.

Most famous Ethiopian cuisine preparations and cooking have structured and explicitly defined normative guides. Moreover, it is implied that these guides demand a great deal of time and leave little room for adaptability. The food recipes are more common and consistent. A couple of research participants have reflected their thoughts on the adverse impact of these food utilization normative guides on dietary diversification and efficiency of labor productivity. The diaspora key informant said:

Many of the famous Ethiopian cuisines are time-demanding. If we see one of the top national cuisines, Doro wot (traditional cuisine made of chicken), it takes a minimum three to four hours, just for cooking. This costs time, reduces efficiency, and discourages people to regularly cook and include it in their daily food menus.

According to almost all key informants, the tradition of animal consecration at home has reduced people's trust in supermarkets, governmental, and non-governmental licensed shops that deliver meat and meat-related foods with labels. For some of the informants (historian, economist, sociologist, and nutritionist), this phenomenon might discourage the expansion of supermarkets and groceries and thereby reduce people's chance of getting food labels.

Studies on the impacts of Ethiopian food norms on the expansion of supermarkets and groceries are insufficient. However, adequate evidence shows that the food supply chain in Ethiopia is traditional and unstable. ${ }^{(52)}$ Supermarkets are a recent phenomenon in the country and "do not have a significant market share in either cereals (one of the most important food categories in Ethiopia) or processed food." "(52) As the economist key informant disclosed; local village shops, cafeterias, restaurants, and open-public markets are the major food (processed and non-processed) trading areas, both in urban and rural areas. For the last two decades, following the country's macroeconomic growth, the expansion of supermarkets and food groceries in major cities have showed promising progress. ${ }^{(13),}$ (15)

The existing mainstream food taboos are strict and deeprooted among the public and this probably has some costs, said economist key informant. Five research participants cited people's strong adherence to taboo foods during the Ethiopian famine of 1984-85 and its aftermath. According to the diaspora key informant, "many lives could have been saved if people 
Table 5.1: Summary of the main adverse impacts of FTP on Ethiopian food security

\begin{tabular}{|c|c|c|c|}
\hline S. NO & DESCRIPTIONS & $\begin{array}{l}\text { SPECIFIC CAUSES OF FOOD } \\
\text { TABOOS \& PREFERENCES }\end{array}$ & $\begin{array}{l}\text { IMPACTS ON FOOD SECURITY (COMPO- } \\
\text { NENTS) }\end{array}$ \\
\hline 1 & $\begin{array}{l}\text { Complete or partial prohibition of } \\
\text { some of the existing eatable plants and } \\
\text { animals }\end{array}$ & $\begin{array}{l}\text { Religious commandment, tradition- } \\
\text { al beliefs, misconceptions or lack of } \\
\text { awareness, and stereotypes in food } \\
\text { preferences }\end{array}$ & $\begin{array}{l}\text { - Causes underutilization of the existing } \\
\text { resources } \\
\text { - } \\
\text { Limits food availability, access, and varieties }\end{array}$ \\
\hline 2 & $\begin{array}{l}\text { Irregularity on size of food production } \\
\text { and consumption }\end{array}$ & Fasting both $O C$ and Muslims & $\begin{array}{l}\text { - Causes price fluctuations on food items } \\
\text { - Discourages investment in the food sector } \\
\text { - Constrains food availability, access, and } \\
\text { stability }\end{array}$ \\
\hline 3 & Supply shortage of food items & OC Fasting & - Limits food availability and access \\
\hline 4 & Price volatility on some food items & OC Fasting & - Affects food accessibility \\
\hline 5 & $\begin{array}{l}\text { Temporary decrease in economic } \\
\text { transactions }\end{array}$ & Fasting both OCs and Muslims & $\begin{array}{l}\text { - Discourages investment in the food sector } \\
\text { - Endures the stability of the food sector }\end{array}$ \\
\hline 6 & $\begin{array}{l}\text { Temporary closure of shops and few } \\
\text { restaurants }\end{array}$ & Fasting, especially among OC & $\begin{array}{l}\text { Discourages investment in the food sector } \\
\text { Endures the stability of the food sector } \\
\text { Limits food availability and access }\end{array}$ \\
\hline 7 & $\begin{array}{l}\text { Irregularity on opening and closing } \\
\text { hours of some shops and other busi- } \\
\text { nesses }\end{array}$ & Fasting, especially among Muslims & $\begin{array}{l}\text { - Discourages investment in the food sector } \\
\text { - Endures the stability of the food sector } \\
\text { - Limits food availability and access }\end{array}$ \\
\hline 8 & $\begin{array}{l}\text { On purpose abstinence from food and } \\
\text { drinks for hours }\end{array}$ & Fasting both OC s and Muslims & $\begin{array}{l}\text { - Impacts labour efficiency and productivity } \\
\text { - Endures the stability of the food sector }\end{array}$ \\
\hline 9 & $\begin{array}{l}\text { The Tradition of animal consecration } \\
\text { at home }\end{array}$ & $\begin{array}{l}\text { Religious commandment and cul- } \\
\text { tural traditions }\end{array}$ & $\begin{array}{l}\text { - Discourages investment in the food sector } \\
\text { - Constrains meat quality check } \\
\text { - Endures the stability of the food sector } \\
\text { - Limits exposure to food labels }\end{array}$ \\
\hline 10 & $\begin{array}{l}\text { Limit access for food labels particularly } \\
\text { on meat products }\end{array}$ & $\begin{array}{l}\text { Tradition of animal consecration at } \\
\text { home }\end{array}$ & $\begin{array}{l}\text { - Limits awareness of food contents and } \\
\text { qualities } \\
\text { - Limits exposure to adaptive food utiliza- } \\
\text { tion } \\
\text { - Limits access to price, size, \& promotion } \\
\text { advantages }\end{array}$ \\
\hline
\end{tabular}

Source: own processing based on the interview Results, 2020

were able to consider taboo foods especially donkey and horse meats which were available during the famine and drought." Likewise, a lecturer at AAU said:

In some countries like China, chronic food insecurity had induced revolutionary change in food norms. It happened as part of a survival strategy. However, in Ethiopia, this kind of progressive change is hardly possible at least this time. At a different time in history, the country has experienced deadly drought and famine which cost the lives of millions. However, none of these has caused a revolutionary change in the mainstream food habits. The changes are all gradual.

In fact, it is noticed that goats, sheep, chickens, cows or bulls, and fish (no other seafood) are the main socially recognized animals for meat in the mainstream food culture, although the country is a home to more than 2800 animal species. ${ }^{(19)}$ Plant species are also exposed to similar food restrictions mostly due to misconceptions and stereotypes in food preferences. "If optimally utilized, banned or less preferred animal and plant species could have contributed immensely for the overall food security status of the country," said the economist key informant.

\section{Discussions and Conclusions}

\subsection{Discussions}

The ultimate aim of this thesis is investigating the impacts of FTP on Ethiopian food security. By definition, food taboos and preferences prohibit and/or limit the consumption and production of certain food items, as they are defined by a society. ${ }^{(5)}$ Especially, when the motives behind the restriction are non-scientific, they can cause adverse consequences on food security. ${ }^{(1),(9)}$ In this regard, the findings obtained in this thesis are neither different nor contradictory from some preexisting study findings. Instead it further substantiates it. Among others, food taboos and preferences have caused the underutilization of easily available food resources in Ethiopia.

Also, according to the research participants, FTP restrains not only socially banned foods but also publicly approved and highly demanded food. Meat is an example of this. Ethiopia is among the countries that consume the least meat and dairy products. ${ }^{(12),(22)}$ The average meat consumption of an Ethio- 
pian adult is $7.4 \mathrm{~kg}$ per year which is half of the Sub-Saharan African average, namely $14 \mathrm{~kg}$ per year. ${ }^{(15)}$ Fasting is the most commonly cited justification for the under-consumption and production of meat and dairy products in Ethiopia. ${ }^{(12),(22),(23)}$ However, in this study, other religiously and culturally defined food taboos and beliefs are found equally as important as fasting. It is noticed that meat consumption is extremely valued in the country yet restrained by the existing food norms in different forms. Meat consumption is associated with cultural and religious rituals. ${ }^{(11)}$ As the sociologist key informant described it, in Ethiopia, meat consumption is defined in a way that people do not easily access, afford, and utilize it. This restriction is expressed throughout all stages of the supply chain and strongly affects meat availability, access, utilization and stability.

Consecration of animals is a long-standing sacred tradition in Christian, Muslim, and Jewish societies. Today, it remains a common practice in Ethiopia. ${ }^{(12)}$ As revealed in the findings section, any socially recognized meat is automatically defined taboo unless sanctified in accordance with on the religious tradition. Out of fear to transgress their religious commandments, the vast majorities of Ethiopian Christians and Muslims neither share meat with each other nor do they feel comfortable to buy it from supermarkets. ${ }^{(11),(12)}$ Hence, animals are often consecrated in the household, either privately or in a group. Mostly, the consecration happens without animals passing through the necessary health and quality check from the concerned authority, especially in the countryside.

Some research participants expressed concerns about the health and economic implications of animal consecration at home. In their opinion, the practice impedes the expansion of supermarkets and food groceries in the country. In turn, this alienates people from access to product labels, quality checks, and price and choice advantages. Most food items in supermarkets have labels that give information about the expiry date, quality checks, utilization instructions, promotions, and nutritional contents. ${ }^{(53),(54)}$ Besides, as stated by the Ethiopian diaspora key informant, the day-to-day exposure to this kind of information can gradually enhance customers' awareness of varied nutrition. He also stated that all the information on food labels are essential components for a healthy diet, yet largely absent in Ethiopia. Moreover, supermarkets offer meat in different forms, sizes, and price categories. Nonetheless, the existing traditions have kept most Ethiopians away from these advantages.

According to multiple published scholarly studies, fasting among Ethiopian OC adversely affects the consumption and production of non-vegan foods. Comparing these findings with the results of this thesis, no basic inconsistencies are observed. However, additional to the previous studies, in this study a spillover effect is observed on the production and consumption of non-fasting foods and drinks, particularly on alcohol consumption. As justified by the sociologist key informant, this is because of the positive correlation between the

\footnotetext{
(53) Hawkes (2010)

(54) WHO (2004)

(55) Ndyetabula \& Hella (2017)

(56) Jian and Rehman (2016)
}

consumption of meat and people's desire for alcoholic drinks in the country. Nonetheless, whether this correlation is significant or not demands further quantitative inquiry. Moreover, during OC fasting days, supply shortage and an increase in the price of vegan foods are mentioned by the research participants. This finding is also supported by the microeconomics consumer theory on substitute goods. Vegan foods are a substitute for meat and dairy products. OC fasting causes the OCs and some non-OCs diet shift from meat and foods of animal origin to complete vegan foods. ${ }^{(23),(24)}$ This increases the demand for vegan foods with probable supply shortage and price increment.

The impact of restricted food habits on food sector investment is discussed by three of the research participants from economics, sociology, and development backgrounds. Their outlook for the different forms of food prohibition is that they will further decrease food consumption and overall business transactions in Ethiopia. This might have a discouraging effect on the country's attempt of attracting local and foreign investors in the entire food sector. After all, investment decisions are made based on feasibility study results which take into account all possible profit opportunities and potential costs. ${ }^{(55)}$ The observation that investment in the food sector is less profitable than in other sectors ${ }^{(56)}$ partly underpins the conferred result.

The joint report of the World Food Program and the Central Statistics Agency of Ethiopia ${ }^{(15)}$ shows that, in 2016, around 54 percent of Ethiopian households used to consume at most four different types of food per week. In the same document, poverty is cited as the main probable reason for the poor figure. However, the evidence obtained in this thesis does not fully support this suggested reason. The evidence also argues against other study findings that exclusively reduce the weakly diversified food intake of Ethiopians into poverty or income limitations. Food diversification is not the main distinction between the rich and poor Ethiopians, according to the interviewees. Rather, an increase in income is more associated with regular meat consumption than with dietary diversification. This observation finding demonstrates that existing food habits are probably equally as important as income constraints for limited diet diversification, which directly affects the food utilization components of food security.

The Ethiopian rich-poor food preferences have a distinctive feature. As shown in the findings, the rich eat meat and high protein content food while the poor consume varieties of grains, cereals, pulses, and some vegetables and fruits. This finding is also supported by literature sources. The poor Ethiopians' easy access to organic vegan food is neither the influence of science nor a healthy lifestyle choice. Instead, it results from the circumstances of small-scale subsistence farmers who have limited access to modern agricultural inputs and inorganic products. As substantiated by multiple sources, ${ }^{(57),(58)}$ fertilizer and pesticide consumption in Ethiopia are below the internationally recommended standard. Nonetheless, both the poor and the rich are not properly taking advantage of the low price of healthy vegan food. The average consumption of fruits and vegetables per person per year in the country is $3.5 \mathrm{~kg}$ and $61 \mathrm{~kg}$ respectively, which is below WHO's minimal consumption recommendation threshold. ${ }^{(15)}$

Research participants have conferred that palatability, avail- 
ability, and income are the main determinants for people's daily food preferences. Health impact or nutritional content are hardly considered, even among educated-higher class Ethiopians. This is explained by the deep-rooted life-long socialization regarding food preferences. This result of the thesis seems contradictory to the common understanding of the positive correlation between educational status and a healthy diet. ${ }^{(59)}$ However, diet change is one of the most challenging tasks for both professionals and the general public. ${ }^{(60)}$

\subsection{Conclusions}

Based on the data collected from the key informants, this thesis investigated how the prevailing culturally and religiously based FTP adversely impact the food security of Ethiopia. Accordingly, it is revealed that some animal and plant species that are edible in many other countries are proscribed and less preferred in Ethiopia, at least by socio-cultural norms. If these edible species were considered, the neglected plants and animals could contribute in mitigating the chronic food insecurity challenge in the country. Besides, parts of the socially approved foods are provisionally banned for fasting and expectations of fitting to the religious and secular normative standards. These provisional bans are hampering the free production and consumption patterns of even renowned foods.

It is also observed that during OCs and Muslims' fasting days, the entire food supply chain undergoes economic turbulence. This economic challenge occurs predominantly during OC fasting days as it leads to (1) a drop in consumption and supply of non-vegan foods, (2) the provisional closure of butcher and dairy shops, (3) an increase in the demand and price of vegan foods, and (4) an overall reduction in consumption and economic transactions, predominantly in the OC dominated areas of the country. Moreover, the tradition of animal consecration at home has made many Ethiopians independent of supermarkets, groceries, and other licensed meat shops. In turn, this impedes the country's endeavor of attracting local and foreign private investors in the entire food sector, impacting food stability. It also alienates people from food labels, meat quality checks, price, size, utilization instruction, and choice advantages, all of which are essential for better, adaptive, and stable food utilization.

Despite these challenges, the adverse impacts of FTP on food security are often turned invisible, taken-for-granted, and overlooked by the concerned authorities, including policy experts. However, systematic consideration of the subject in policy cycles aiming to end food insecurity would provide the country with additional strength in the fight against food insecurity.

\footnotetext{
(57) Endale (2011)

(58) Bachewe, Berhane, Minten, and Taffesse (2018)

(59) Li and Powdthavee (2014)

${ }^{(60)}$ O'Riordan and Stoll-kleemann (2015)
}

\section{Acknowledgment}

This work would not have been feasible

without the guidance and constructive feedbacks of

Prof. dr. ir. Marijke D'Haese,

Mr. Chinedu Ob,

Mrs. Fatemeh Taheri, and

Miss Sofie Devos.

Hence, I would like to thank you all

for your indispensable professional contribution.

\section{References}

1. Alonso, E. B., Cockx, L., \& Swinnen, J. (2017). Culture and Food Security (Discussion Paper 398/2017 No. 398/2017). 3000 Leuven, Belgium.

2. Clinard, M. B., \& Meier, R. F. (2011). Sociology of Deviant Behavior (14th ed.). Belmont, CA 94002-3098: USA: Wadsworth, Ceagagelearning.

3. Chekroun, P. (2018). Social Control Behavior: The Effects of Social Situations and Personal Implication on Informal Social Sanctions. Social and Personality Psychology Compass, 2(6), 2141-2158.

4. Smith, M. L. (2008). The Archaeology of Food Preference. American Anthropological Association, 108(3), 480-493.

5. Meyer-Rochow, V. B. (2009). Food taboos: their origins and purposes. Journal of Ethnobiology and Ethnomedicine, 5(18), 1-10.

6. Onuorah, C. E., \& Ayo, J. A. (2003). Food taboos and their nutritional implications on developing nations like Nigeria - A review. Nutrition \& Food Science, 33(5), 235-240.

7. Schuurmans, T. A. (2014). Food cultures, eating insects and the future. Wageningen University Department of Sciology.

8. Schulz, F. (2020). Are Europeans ready for an insect- based diet? Euroactive, pp. 1-5. Retrieved from https://www.euractiv.com/ section/agriculture-food/news/are-europeans-ready-for-an-insect-based-diet/

9. HLPE. (2017). Nutrition and food systems. A report by the High Level Panel of Experts on Food Security and Nutrition of the Committee on World Food Security: Rome, Italy.

10. FAO. (2008). An Introduction to the Basic Concepts of Food Security. Rome, Italy: EC - FAO Food Security Programme. Retrieved August 13, 2020, from http://www.fao.org/3/a-al936e.pdf

11. Seleshe, S., Jo, C., \& Lee, M. (2014). Meat Consumption Culture in Ethiopia. Korean Journal for Food Science of Animal Resources, 34(1), $7-13$

12. Hopf, W. (2017). Ethiopia: History, Culture and Challenges. (S. Uhlig, D. Appleyard, A. Bausi, W. Hahn, \& S. Kaplan, Eds.). Berlin: Lit Verlag.

13. Cheru, F., Christopher, C., \& Oqubay, A. (Eds.). (2019). The Oxford Handbook of the Ethiopian Economy. New York, NY: Oxford University Press.

14. Gill, P. (2010). Famine and Foreigners: Ethiopia since Live Aid. New York, NY: Oxford University Press.

15. WFP, \& CSA. (2019). Comprehensive Food Security and Vulnerability Analysis (CFSVA). Addis Ababa, Ethiopia.

16. WB. (2019). The World Bank in Ethiopia. Retrieved April 29, 2020, from https://www.worldbank.org/en/country/ethiopia/overview

17. UN. (2015). Transforming our World: The 2030 Agenda for Sustainable Development. New York. Retrieved from https://sustainabledevelopment.un.org

18. FAO. (2019a). Africa Regional Synthesis for the State of the World's Biodiversity for Food and Agriculture. Rome, Italy.

19. EBI. (2014). Ethiopia's Fifth National Report to the Convention on Biological Diversity. Addis Ababa, Ethiopia.

20. Crummey, D. E., \& Mehretu, A. (2019). Ethiopia. In Encyclopædia Britannica. Encyclopædia Britannica, inc. Retrieved from https:// 
www.britannica.com/place/Ethiopia

21. Olum, S., Okello-uma, I., Tumuhimbise, G. A., Taylor, D., \& Ongeng, D. (2017). The Relationship between Cultural Norms and Food Security in the Karamoja Sub-Region of Uganda. Journal of Food and Nutrition Research, 5(6), 427-435.

22. Rogers, K. (2020). Health wellness. Want to eat less meat? Take a page from these cultures that already do. CNN: New York, USA: Turner Broadcasting System, Inc.

23. D'Haene, E., Desiere, S., D'Haese, M., Verbeke, W., \& Schoors, K. (2019). Religion, Food Choices, and Demand Seasonality: Evidence from the Ethiopian Milk Market. Food, 8(167), 1-21.

24. Belwal, R., \& Tafesse, Y. (2010). A study of the impact of orthodox Christians' fasting on demand for biscuits in Ethiopia. African Journal of Marketing Managemen, 2(1), 10-17.

25. Esler, P. F. (2019). Ethiopian Christianity: History, Theology, Practice. Waco: Baylor University Press.

26. Sadeghirad, B., Motaghipisheh, S., Kolahdooz, F., Zahedi, M. J., $\&$ Haghdoost, A. A. (2012). Islamic fasting and weight loss: a systematic review and meta-analysis. Public Health Nutrition, 17(2), 396-406.

27. Zerfu, T. A., Umeta, M., \& Baye, K. (2016). Dietary habits, food taboos, and perceptions towards weight gain during pregnancy in Arsi, rural central Ethiopia: a qualitative cross-sectional study. Journal of Health, Population and Nutrition, 35(22), 1-7.

28. Abidoye, R. O., \& Akinpelumi, O. B. (2010). Implications of Nutritional Beliefs and Taboos Hausa and Yoruba Pregnant Women in Lagos Nigeria. Early Child Development and Care, 138(1), 71-81.

29. Aikins, A. de-G. (2014). Food Beliefs and Practices During Pregnancy in Ghana: Implications for Maternal Health Interventions. Health Care for Women International, 35(7-9), 954-972.

30. Maliwichi-Nyirenda, C. P., \& Maliwichi, L. L. (2017). Food Related Taboos Observed During Pregnancy in Malawi 2017. Studies on Ethno-Medicine, 10(2), 263-268.

31. Christian, P., Srihari, S. B., Throne-Lyman, A., Khatry, S. K., LeClerq, S. C., \& Shrestha, S. R. (2007). Eating Down in Pregnancy: Exploring Food-Related Beliefs and Practices of Pregnancy in Rural Nepal. Ecology of Food and Nutrition, 45(4), 253-278.

32. Maxwell, D. G. (1996). Measuring food insecurity: the frequency and severity of "coping strategies." Food Policy, 21(3), 291-303.

33. World Food Summit. (1996). Rome Declaration on World Food Security. Rome, Italy. Retrieved from http://www.fao.org/3/ w3613e/w3613e00.htm

34. WFP. (2009). Emergency Food Security Assessment Handbook (2nd ed.). Rome, Italy. Retrieved from www.wfp.org

35. Napoli, M. (2011/12). Towards a Food Insecurity Multidimensional Index (FIMI ). Roma Tre. Retrieved from http://www.fao.org/ fileadmin/templates/ERP/uni/FIMI.pdf

36. Worldometer. (2020). Ethiopian Population. Dover, Delaware, U.S.A. Retrieved from https://www.worldometers.info/worldpopulation/ethiopia-population/

37. Adamu, A. Y. (2013). Diversity in Ethiopia. A Historical Overview of Political Challenges. The International Journal of Community Diversity, 12(3), 17-27.

38. CSA. (2010). Population and Housing Census 2007 Report, National Central Statistical Agency of Ethiopia. Addis Ababa, Ethiopia.

39. Clapham, C. (2018). The Ethiopian Developmental state. Third World Quarterly, 39(6), 1151-1165.

40. Bhandari, P., \& Ghimire, D. (2016). Rural Agricultural Change and Individual Out-migration. Rural Sociol, 81(4), 576-600.

41. Arendonk, A. Van. (2015). The Development of the Share of Agriculture in GDP and Employment: A Case Study of China, Indonesia, the Netherlands and the United States. Wageningen University. Retrieved from https://pdfs.semanticscholar.org

42. Dennis, B. N., \& Talan, B. (2007). Productivity growth and agricultural out-migration in the United States. Journal of Structural Change and Economic Dynamics, 18, 52-74.

43. Todaro, M. P., \& Smith, S. C. (2015). Economic Development
Twelfth Edition (12 ed.). New York: Pearson.

44. Taylor, S. J., Bogdan, R., \& DeVault, M. (2016). Introduction to Qualitative Research Methods: A Guidebook and Resource. Hoboken, New Jersey: John Wiley \& Sons Inc.

45. Flick, U. (2018). An Introduction to Qualitative Research. (A. Owen, Ed.) (6th ed.). Los Angeles: SAGE Publication Ltd.

46. Payne, G., \& Payne, J. (2004). Key Concepts in Social Research. London ECIY ISP: Sage Publications Ltd.

47. Wertz, F., Charmaz, K., McMullen, L., Anderson, R., \& McSpadden, E. (2011). Five Ways of Doing Qualitative Research. New York: Guilford Press.

48. Rubin, H. J., \& Rubin, I. S. (2004). Qualitative Interviewing: The Art of Hearing Data (2nd ed.). Thousand Oaks, CA: SAGE Publications.

49. Abaïdia, A.-E., Daab, W., \& Bouzid, M. A. (2020). Effects of Ramadan Fasting on Physical Performance: A Systematic Review with Meta - analysis. Sports Medicine, 50, 1009-1026.

50. FAO. (2019b). Africa sustainable livestock 2050. The Future of livestock in Ethiopia: Challenges in the faces of uncertainty. Food and Agriculture Organization of the United Nations: Rome, Italy. Retrieved from http://www.fao.org/3/ca4807en/ca4807en.pdf

51. Abebe, B., Zelalem, Y., Mitiku, E., \& Yousuf, M. K. (2020). The Ethiopian dairy sector with focus on traditional butter: A Review. African Journal of Food, Agriculture, Nutrition and Development, 20(1), 15267-15286.

52. Soethoudt, H., Riet, J. van der, Sertse, Y., \& Groot, J. (2013). Food processing in Ethiopia. Addis Ababa, Ethiopia. Retrieved from www.wageningenUR.nl

53. Hawkes, C. (2010). 4 - Government and voluntary policies on nutrition labelling: a global overview. In J. Albert (Ed.), Innovations in Food Labelling (pp. 37 -58). New York: Woodhead Publishing Ltd.

54. WHO. (2004). Global Strategy on Diet, Physical Activity and Health. World Health Organization: Geneva, Switzerland.

55. Ndyetabula, D., \& Hella, J. (2017). Agribusiness Project Appraisal: Theory and Applications. London, United Kingdom: Adonis \& Abbey Publishers Ltd.

56. Jian, W., \& Rehman, A. (2016). Risk Management in Agricultural: - Theories and Methods. New York, NY 10018, U.S.A: Science Publishing Group.

57. Endale, K. (2011). Fertilizer Consumption and Agricultural Productivity in Ethiopia (EDRI Working Paper No. 003). Ethiopian Development Research Institute: Addis Ababa, Ethiopia.

58. Bachewe, F. N., Berhane, G., Minten, B., \& Taffesse, A. (2018). Agricultural Transformation in Africa? Assessing the Evidence in Ethiopia. International Food Policy Research Institute, 105, 286-298.

59. Li, J., \& Powdthavee, N. (2014). Does more education lead to better health habits? Evidence from the school reforms in Australia. Social Science \& Medicine, 127, 83-91.

60. O'Riordan, T. O., \& Stoll-kleemann, S. (2015). The Challenges of Changing Dietary Behavior Toward More Sustainable Consumption. Environment Science and Policy for Sustainable Develop

Contact address/ Kontaktná adresa

Alex Sewenet PhD. Candidate,

Department of European Policies,

Faculty of European Studies and Regional Development,

Slovak University of Agriculture in Nitra,

e-mail: xsewenet@uniag.sk

Prof. Ing. Pavol Schwarcz, PhD.

Department of European Policies,

Faculty of European Studies and Regional Development,

Slovak University of Agriculture in Nitra,

e-mail: pavol.schwarcz@uniag.sk 